RASĀYAN J. Chem.

Vol. 13 | No. 4 |2390-2400| October - December | 2020 ISSN: 0974-1496 | e-ISSN: 0976-0083 | CODEN: RJCABP

\title{
SEASONAL VARIATION OF TRACE AND HEAVY METALS IN VEGETABLE PLANTS AROUND TUMMALAPALLE URANIUM MINING SITE
}

\author{
S. Kulavardhana Reddy ${ }^{1}$, C. Sivanandha Reddy ${ }^{1, *}$ and Gopireddy Venkata \\ Subba Reddy ${ }^{2}$ \\ ${ }^{1}$ Department of Chemistry, Sri Chaitanya College, Madhavaram, Chennai, T.N-6000060, India \\ ${ }^{1,2}$ Department of Chemistry, JNTUA College of Engineering (Autonomous), Pulivendula, YSR \\ (Kadapa) dist, A.P -516 390, India. \\ E-mail: chanda.sivanandareddy@gmail.com
}

\begin{abstract}
This study has investigated the source and magnitude of trace and heavy metal contamination of various kinds of vegetable plants in the close vicinity of the uranium mining area during the pre-monsoon and post-monsoon seasons. All vegetable samples were collected from the selective agricultural fields and analyzed by Inductive Coupled Plasma Optical Emission Spectroscopy (ICP-OES). The mean concentrations of trace and heavy metals in vegetable plants were found to be in the range of $0.01-0.24$ 49.27-56.41, 0.028-4.65, 0.72-6.29, 35.05-73.47, 12.44-19.61, 0.014-0.068, 0.029-0.18, 2.081-7.52, 0.022-0.28, 0.01-3.01, 0-0.008 B, Ca, Cu, Fe, K, Mg, Mn, Mo, P, Zn, Pb, and Se in pre-monsoon season. During the post-monsoon season 0.14-1.09,45.64-57, 0.45-3.54, 37.33-62.44, 67.73-89.3 , 12.45-23.32, 0.65-4.87, 0.53-2.96, 21.65-28.3, 0.35-1.12, 0.028-0.61, 0.013-0.097 B, Ca, Cu, Fe, K, $\mathrm{Mg}, \mathrm{Mn}, \mathrm{Mo}, \mathrm{P}, \mathrm{Zn}, \mathrm{Pb}$ and Se found in plants. The trace and heavy metals were observed in the field and compared with the literature values and some guidelines. The trace and heavy elemental data were analyzed through statistical tools to examine the interrelationship among the investigated trace and heavy elements and possible source identification of the trace metal contamination in vegetable plants.

Keywords: Environmental Quality, Vegetable Plants, Trace and Heavy Metals, ICP-OES, Accumulation, Pre and Post-monsoon Seasons.
\end{abstract}

(C) RASĀYAN. All rights reserved

\section{INTRODUCTION}

The global changes extend new challenges in environmental preservation and conservation; experimental values of fields will help to measure the potential impact on the ecosystem. Local Mining activities are one of the causes of polluting the agricultural soils and it is great agitation in the environment. During the mining activities, such as extraction of metals, release large quantities of tailings and waste containing heavy and trace metals which cause a critical hazard to water resources, agricultural soils and cultivated food crops.

Recently, the public has more awareness of food safety worldwide. During the last decades, the increasing demand for food safety has stimulated research regarding the risk associated with the consumption of foodstuffs contaminated by pesticides, heavy metals and/or toxins. ${ }^{1}$ Contamination of vegetables with heavy metal may be due to irrigation with contaminated water, the addition of fertilizers and metal-based pesticides, industrial emissions, transportation, the harvesting process, storage, or at the point of sale. It is well known that plants take up metals by absorbing them from contaminated soil as well as from deposits on parts of the plants exposed to the air from polluted environment., ${ }^{2,3}$

To full fill of nutrient balance, humans have been taking vegetables and are an essential part of the human diet. Vegetables are a rich source of an important source of carbohydrates, vitamins, minerals and fibers. Heavy metals can be readily taken up by vegetable roots and can be accumulated at high levels in the edible parts of vegetables, even at low levels in the soil., ${ }^{4,5}$ Trace metals can be classified as potentially toxic (Cd, As, $\mathrm{Hg}, \mathrm{Cr}$ etc.), probably essential (Ni, Co and $\mathrm{V}$ ) and essential (Fe $\mathrm{Zn}, \mathrm{Mg}, \mathrm{K}, \mathrm{P}, \mathrm{Mn}$ and

Rasayan J. Chem., 13(4), 2390-2400(2020)

http://dx.doi.org/10.31788/ RJC.2020.1345869

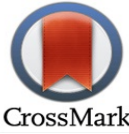


RASĀYAN J. Chem.

Vol. 13 | No. 4 |2390-2400| October - December | 2020

$\mathrm{Cu}$ ). Some toxic metals are harmful even at low concentrations when consumed over a long period. The essential metals may also create toxic effects when metal intake is too high. ${ }^{6}$

Bioaccumulation of metals in plants is dependent on many factors includes metal concentration and speciation, characteristics of soil and plant species, variations in plant species and physiological modifications, and plant growth stage. The roots of a plant are the primary contact site for trace metal ions; they can play an important role in metal accumulation via filtration, adsorption and cation exchange, and through a plant-induced chemical change in the rhizoshpere. ${ }^{7}$ Because of the potential human health risks, the accumulation of trace metals in soils and plants (vegetables) is of growing concern. Through the food chain, toxic pollutants can be entered into the human body and may cause interference of the biological and biochemical process. ${ }^{8}$

The main objective of the present study was to observe any possible seasonal variation in the distribution of trace and heavy metals in various vegetable plants around the Tummalapalle uranium mining site.

\section{EXPERIMENTAL}

\section{Study Area}

The study area and uranium underground mining site is located in and around Tummalapalle village, YSR District, Andhra Pradesh, India. The mining site is located between latitudes $14^{\circ} 18^{\prime} 36^{\prime \prime} \mathrm{N}$ and $14^{\circ} 20^{\prime} 20^{\prime}$ ' $\mathrm{N}$ and longitudes $78^{\circ} 15^{\prime} 16^{\prime \prime} \mathrm{E}$ and $78^{\circ} 18^{\prime} 03.3 \mathrm{E}$ according to a survey of Indian Toposheet Nos. $57 \mathrm{~J} / 3$ and $57 \mathrm{~J} / 7$. The selected agricultural (five) fields are located around the mining area and locations are shown in Fig.-1 and Table-1.

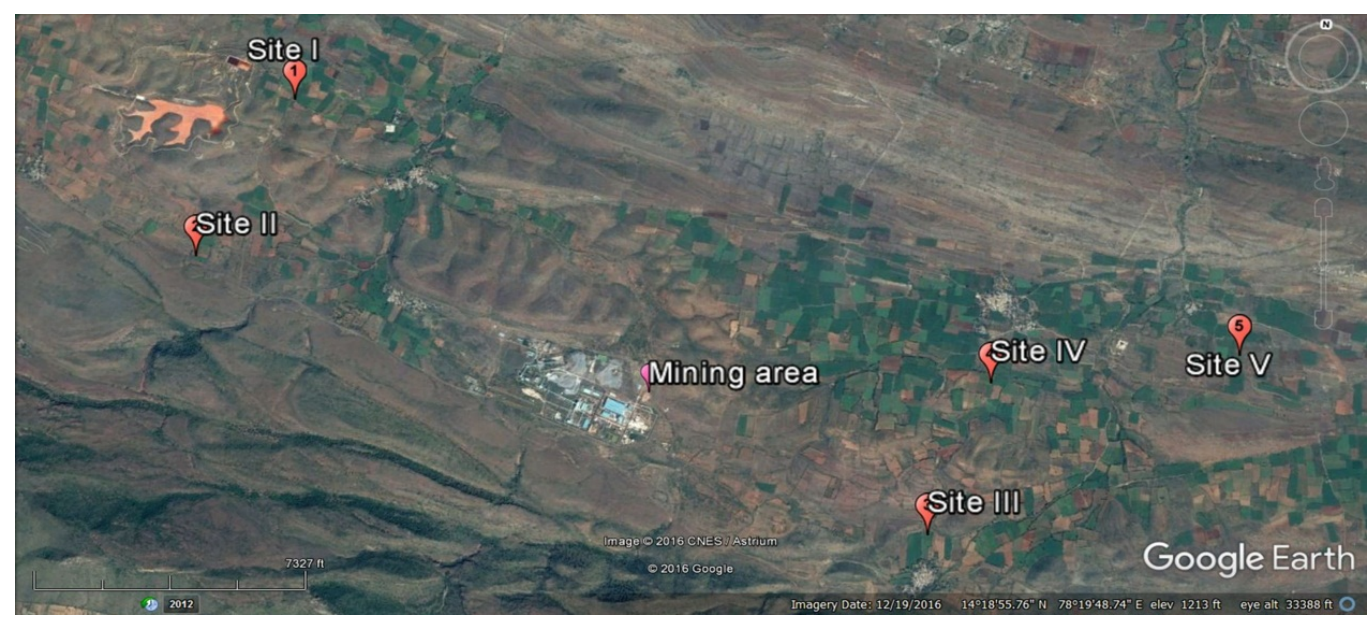

Fig.-1: Geographical Distribution of the Sampling Locations

Table-1: Location Names, Latitudes/Longitudes and Distance from the Mining Area

\begin{tabular}{c|c|c|c|c}
\hline S. No. & Location & $\begin{array}{c}\text { Distance from the } \\
\text { Mining Site }(\mathrm{km})\end{array}$ & Latitude & Longitude \\
\hline 1 & Mabbuchinthala palle (site I) & 5 & $14^{0} 20^{\prime} 34.92^{\prime \prime} \mathrm{N}$ & $78^{0} 14^{\prime} 40.32^{\prime \prime} \mathrm{E}$ \\
\hline 2 & Mabbuchinthala palle (site II) & 7 & $14^{0} 19^{\prime} 45.84^{\prime \prime} \mathrm{N}$ & $78^{0} 14^{\prime} 17.76^{\prime} \mathrm{E}$ \\
\hline 3 & Rachakunta palle (site III) & 2 & $14^{0} 18^{\prime} 39.60^{\prime \prime} \mathrm{N}$ & $78^{0} 17^{\prime} 48.30^{\prime \prime} \mathrm{E}$ \\
\hline 4 & Bhumaiagari palle (site IV) & 3 & $14^{0} 19^{\prime} 24.54^{\prime \prime} \mathrm{N}$ & $78^{0} 18^{\prime} 03.48^{\prime \prime} \mathrm{E}$ \\
\hline 5 & Bhumaiagari palle (site V) & 8 & $14^{0} 19^{\prime} 37.74^{\prime \prime} \mathrm{N}$ & $78^{0} 19^{\prime} 12.60^{\prime \prime} \mathrm{E}$ \\
\hline
\end{tabular}

\section{Instrumentation}

All samples were analyzed with Perkinelmer 7000 DV ICP-OES and optimized conditions shown in Table-2.

\section{Method Description}

The emission lines of standard metal ions are selected according to the ionization potential and the type of the analyte line. All metal ions were measured at different wavelength range such as B at $249.677 \mathrm{~nm}$, 
RASĀYAN J. Chem.

Vol. 13 | No. 4 |2390-2400| October - December | 2020

$\mathrm{Ca} 317.933 \mathrm{~nm}, \mathrm{Cu}$ at $317.933 \mathrm{~nm}, \mathrm{Fe}$ at $238.204 \mathrm{~nm}, \mathrm{~K}$ at $766.490 \mathrm{~nm}, \mathrm{Mg}$ at $285.213 \mathrm{~nm}$,Mn at $257.610 \mathrm{~nm}$, Mo at $202.031 \mathrm{~nm}, \mathrm{P}$ at $213.617 \mathrm{~nm}, \mathrm{Zn}$ at $206.200 \mathrm{~nm}, A s$ at $193.696 \mathrm{~nm}, \mathrm{Cd}$ at $228.802 \mathrm{~nm}$ ,Pb at $220.353 \mathrm{~nm}$,Seat $196 \mathrm{~nm}$, Ti $276.787 \mathrm{~nm}$.

Table-2: ICP-OES Operation Conditions

\begin{tabular}{c|c}
\hline Injector & Alumina $2 \mathrm{~mm}$ \\
\hline Sample tubing & Standard $0.76 \mathrm{~mm}$ \\
\hline Drain tubing & Standard $1.14 \mathrm{~mm}$ i.d \\
\hline Quartz torch & Single-slot \\
\hline Sample capillary & PTFE1 $\mathrm{mm}$ i.d \\
\hline Source equilibrium delay & Wet \\
\hline Plasma aerosol type & Instant \\
\hline Nebulizer start up & $0.7 \mathrm{~L} / \mathrm{m}$ \\
\hline Auxilary flow & $15 \mathrm{~mL} / \mathrm{min}$ \\
\hline Plasma flow & $1.5 \mathrm{~mL} / \mathrm{min}$ \\
\hline Sample pump rate & Axial,radial \\
\hline Plasma viewing & Peak area \\
\hline Processing mode & $0.1-0.5$ sec \\
\hline Auto integration & 2 \\
\hline Replicates & 1 or2 pont, manual \\
\hline Background correction &
\end{tabular}

\section{Collection of Vegetable Plant Samples}

Vegetable plant samples were collected seasonally (pre and post-monsoon) from five selected agricultural fields around tummalapalle uranium mining site. The vegetable crops were collected in pre-monsoon namely tomato (Solanum lycopersicum) in four sites, onion (Alliumcepa) in one site and during postmonsoon samples such as green chilli (Capsicum annum), brinjal (Solanum melongena), tomato (Solanum lycopersicum), okra (Abelmoschus esculentus) and groundnut (Arachis hypogaea) cultivated in selective fields. The vegetable plant samples are taken in polyethylene bags and brought to the laboratory. The collected plant samples were cleaned with distilled water to remove the dust particles and separated the plant parts into the roots, stems, leaves and fruits. The separated plant parts are shade dried in the laboratory for 48 hours, after that plant parts are placed in a hot air oven for 5-6 hours at $100{ }^{\circ} \mathrm{C}$ to remove excess moisture content. The plant parts are taken from the oven crushed and ground into $2 \mathrm{~mm}$ mesh size using a commercial blender. The prepared plant sample powders are stored in polyethylene bags for the further usage of acid digestion.

\section{Sample Processing and Analysis}

Dried plant powder samples of $0.5 \mathrm{gm}$ taken in $100 \mathrm{ml}$ beaker were digested with $10 \mathrm{ml}$ conc. $\mathrm{HNO}_{3}$ and 2-4 $\mathrm{ml} \mathrm{70 \%} \mathrm{conc.} \mathrm{HClO}_{4}$. Then, the beaker was kept on a hot plate, heated up to $100{ }^{\circ} \mathrm{C}$ until the sample was completely digested. After that, the digested samples were cooled to room temperature and then filtered into $100 \mathrm{ml}$ volumetric flask using Whatman No.42 filter paper and made up to the mark with distilled water. The blank solution was also prepared in a similar procedure. ${ }^{9}$ The prepared samples have been analyzed for quantitative estimation of trace and heavy metal using Inductively Coupled PlasmaOptical Emission Spectroscopy (ICP-OES; model Perkin Elmer 7000DV).

\section{RESULTS AND DISCUSSION}

The trace and heavy metal concentration levels in different vegetable plants from pre and postmonsoon season in and around tummalapalle uranium mining site were analyzed and obtained data tabulated in Table-1. From the literature survey, reported values for vegetable plants from various regions of the world are listed in Table-3. 
RASĀYAN J. Chem.

Vol. 13 | No. 4 |2390-2400| October - December | 2020

Table-3: Trace and Heavy Metal (mg/kg) Concentrations of Vegetable Plant Parts in Pre and Post-monsoon Seasons

\begin{tabular}{|c|c|c|c|c|c|c|c|c|c|c|c|c|c|c|c|c|}
\hline \multicolumn{17}{|c|}{ Pre-monsoon } \\
\hline \multirow{2}{*}{ Plants } & \multirow{2}{*}{$\begin{array}{l}\text { Plant } \\
\text { Parts }\end{array}$} & \multicolumn{15}{|c|}{ Trace and Heavy Metal Concentrations (mg/kg) } \\
\hline & & $\mathrm{B}$ & $\mathrm{Ca}$ & $\mathrm{Cu}$ & $\mathrm{Fe}$ & $\mathrm{K}$ & $\mathrm{Mg}$ & $\mathrm{Mn}$ & Mo & $\mathrm{P}$ & $\mathrm{Zn}$ & As & $\mathrm{Cd}$ & $\mathrm{Pb}$ & $\mathrm{Se}$ & $\mathrm{Tl}$ \\
\hline \multirow{6}{*}{ Tomato } & Roots & 0.23 & 46.55 & 2.58 & 1.17 & 39.73 & 10.61 & 0 & 0.025 & 1.036 & 0.095 & 0 & 0 & 0.013 & 0 & 0 \\
\hline & Stem & 0.14 & 40.88 & 3.58 & 0.39 & 65.22 & 1.18 & 0 & 0.041 & 2.12 & 0.061 & 0 & 0 & 0.016 & 0 & 0 \\
\hline & Leaf & 0.21 & 73.88 & 4.08 & 0.39 & 55.96 & 22.23 & 0.059 & 0 & 3.58 & 0.005 & 0 & 0 & 0.013 & 0 & 0 \\
\hline & Fruit & 0.2 & 47.81 & 3.19 & 0.96 & 54 & 15.77 & 0 & 0.079 & 1.59 & 0.092 & 0 & 0 & 0.019 & 0 & 0 \\
\hline & Mean & 0.19 & 52.28 & 3.35 & 0.72 & 53.72 & 12.44 & 0.014 & 0.036 & 2.081 & 0.063 & 0 & 0 & 0.015 & 0 & 0 \\
\hline & SD & 0.038 & 14.71 & 0.63 & 0.39 & 10.53 & 8.88 & 0.029 & 0.033 & 1.092 & 0.041 & 0 & 0 & 0.002 & 0 & 0 \\
\hline \multirow{6}{*}{ Tomato } & Roots & 0.31 & 48.03 & 1.86 & 1.82 & 37.86 & 11.56 & 0 & 0.033 & 2.65 & 0.18 & 0 & 0 & 0.015 & 0 & 0 \\
\hline & Stem & 0 & 40.97 & 0 & 0.41 & 73.04 & 18.91 & 0 & 0.022 & 5.26 & 0.17 & 0 & 0 & 0.014 & 0 & 0 \\
\hline & Leaf & 0.033 & 85.81 & 0.27 & 1.049 & 50.6 & 16.5 & 0.101 & 0.036 & 6.32 & 0.59 & 0 & 0 & 0.02 & 0 & 0 \\
\hline & Fruit & 0.15 & 49.98 & 0.95 & 1.39 & 57.13 & 16.79 & 0 & 0.027 & 4.094 & 0.2 & 0 & 0 & 0.017 & 0 & 0 \\
\hline & Mean & 0.12 & 56.19 & 0.77 & 1.16 & 54.65 & 15.94 & 0.025 & 0.029 & 4.58 & 0.28 & 0 & 0 & 0.016 & 0 & 0 \\
\hline & SD & 0.14 & 20.11 & 0.82 & 0.59 & 14.63 & 3.11 & 0.05 & 0.006 & 1.57 & 0.2 & 0 & 0 & 0.002 & 0 & 0 \\
\hline \multirow{4}{*}{ Onion } & Roots & 0.021 & 74.61 & 0.057 & 12.44 & 40.35 & 19.36 & 0.13 & 0.34 & 7.842 & 0.161 & 0 & 0 & 0.038 & 0.009 & 0 \\
\hline & Fruit & 0 & 23.94 & 0 & 0.15 & 29.76 & 8.03 & 0 & 0.028 & 7.2 & 0.222 & 0 & 0 & 0.024 & 0.007 & 0 \\
\hline & Mean & 0.01 & 49.27 & 0.028 & 6.29 & 35.05 & 13.69 & 0.068 & 0.18 & 7.52 & 0.191 & 0 & 0 & 0.031 & 0.008 & 0 \\
\hline & SD & 0.014 & 35.82 & 0.04 & 8.69 & 7.48 & 8 & 0.096 & 0.22 & 0.45 & 0.043 & 0 & 0 & 0.009 & 0.001 & 0 \\
\hline \multirow{6}{*}{ Tomato } & Roots & 0.28 & 33.47 & 2.56 & 3.65 & 26.37 & 8.88 & 0 & 0.11 & 0.25 & 0.45 & 0 & 0 & 0.029 & 0 & 0 \\
\hline & Stem & 0.21 & 45.01 & 6.18 & 0.4 & 134.8 & 27.7 & 0 & 0 & 8.06 & 0.16 & 0 & 0 & 0.006 & 0 & 0 \\
\hline & Leaf & 0.24 & 90.42 & 4.77 & 0.36 & 36.25 & 18.71 & 0 & 0.033 & 2.3 & 0.055 & 0 & 0 & 0.009 & 0 & 0 \\
\hline & Fruit & 0.25 & 49 & 5.1 & 2.1 & 96.47 & 23.16 & 0 & 0.098 & 4.51 & 0.34 & 0 & 0 & 0.022 & 0 & \\
\hline & Mean & 0.24 & 54.47 & 4.65 & 1.62 & 73.47 & 19.61 & 0 & 0.06 & 3.78 & 0.25 & 0 & 0 & 0.01 & 0 & 0 \\
\hline & SD & 0.028 & 24.85 & 1.51 & 1.57 & 51.29 & 8.04 & 0 & 0.052 & 3.34 & 0.17 & 0 & 0 & 0.016 & 0 & 0 \\
\hline \multirow{6}{*}{ Tomato } & Roots & 0.19 & 46.97 & 4.27 & 1.8 & 35.61 & 9.84 & 0 & 0.1 & 1.39 & 0.003 & 0 & 0 & 12 & 0 & 0 \\
\hline & Stem & 0.16 & 40.77 & 1.11 & 0.48 & 89.09 & 15.6 & 0 & 0.03 & 6.72 & 0.009 & 0 & 0 & 0.013 & 0 & 0 \\
\hline & Leaf & 0.21 & 89.49 & 2.86 & 0.4 & 51.95 & 19.52 & 0 & 0.009 & 3.9 & 0.045 & 0 & 0 & 0.016 & 0 & 0 \\
\hline & Fruit & 0.19 & 48.42 & 2.85 & 1.44 & 62.07 & 14.4 & 0 & 0.054 & 3.79 & 0.033 & 0 & 0 & 0.015 & 0 & 0 \\
\hline & Mean & 0.18 & 56.41 & 2.77 & 1.03 & 59.68 & 14.84 & 0 & 0.048 & 3.95 & 0.022 & 0 & 0 & 3.01 & 0 & 0 \\
\hline & SD & 0.02 & 22.29 & 1.29 & 0.69 & 22.43 & 3.98 & 0 & 0.039 & 2.17 & 0.019 & 0 & 0 & 5.99 & 0 & 0 \\
\hline
\end{tabular}

Continued Table-3

Post-monsoon

\begin{tabular}{|c|c|c|c|c|c|c|c|c|c|c|c|c|c|c|c|c|}
\hline \multirow{2}{*}{ Plants } & \multirow{2}{*}{$\begin{array}{l}\text { Plant } \\
\text { parts }\end{array}$} & \multicolumn{15}{|c|}{ Trace and Heavy Metal Concentrations $(\mathrm{mg} / \mathrm{kg})$} \\
\hline & & $\mathrm{B}$ & $\mathrm{Ca}$ & $\mathrm{Cu}$ & $\mathrm{Fe}$ & $\mathrm{K}$ & $\mathrm{Mg}$ & $\mathrm{Mn}$ & Mo & $\mathrm{P}$ & $\mathrm{Zn}$ & As & $\mathrm{Cd}$ & $\mathrm{Pb}$ & $\mathrm{Se}$ & $\mathrm{Tl}$ \\
\hline \multirow{4}{*}{ Mirchi } & oots & 1.2 & 48.8 & 3.78 & 58.8 & 74 & 23.4 & 5.6 & 3 & 29.8 & 1.4 & 0 & 0 & 0.7 & 0.16 & 0 \\
\hline & Stem & 1.16 & 72 & 4.2 & 02 & 84 & 24 & 6.8 & 3.8 & 31.2 & 1 & 0 & 0 & 0.024 & 0.1 & 0 \\
\hline & Leaf & 0.92 & & 3.2 & 59.6 & 77.4 & & 5 & 3 & 27 & 1.28 & 0 & 0 & 1.08 & 0.12 & 0 \\
\hline & Fruit & 1.08 & 58.12 & 3 & 69.36 & 88.18 & 25.28 & 2.1 & 2.04 & 25.2 & 0.8 & 0 & 0 & 0.64 & 0.01 & 0 \\
\hline
\end{tabular}


RASĀYAN J. Chem.

Vol. 13 | No. 4 |2390-2400| October - December | 2020

\begin{tabular}{|c|c|c|c|c|c|c|c|c|c|c|c|c|c|c|c|c|}
\hline & Mean & 1.09 & 57.23 & 3.54 & 62.44 & 80.89 & 23.32 & 4.87 & 2.96 & 28.3 & 1.12 & 0 & 0 & 0.61 & 0.097 & 0 \\
\hline & SD & 0.12 & 10.68 & 0.54 & 4.8 & 6.38 & 1.97 & 1.99 & 0.72 & 2.7 & 0.27 & 0 & 0 & 0.43 & 0.063 & 0 \\
\hline \multirow{6}{*}{ Brinjal } & Roots & 0.1 & 61 & 2 & 36 & 82 & 16 & 1.36 & 0.4 & 23.04 & 0.24 & 0 & 0 & 0.1 & 0.01 & 0 \\
\hline & Stem & 0.2 & 56.8 & 1.8 & 51.2 & 71.2 & 10.6 & 1.08 & 1.04 & 25.2 & 0.3 & 0 & 0 & 0.05 & 0.016 & 0 \\
\hline & Leaf & 0.04 & 42.1 & 0.38 & 62 & 66.4 & 19 & 0.6 & 0.54 & 20.18 & 0.6 & 0 & 0 & 0.078 & 0.008 & 0 \\
\hline & Fruit & 1.2 & 52 & 1.06 & 47.8 & 78 & 20 & 1.5 & 0.16 & 22 & 0.56 & 0 & 0 & 0.04 & 0.02 & 0 \\
\hline & Mean & 0.38 & 52.97 & 1.31 & 49.25 & 74.4 & 16.4 & 1.13 & 0.53 & 22.6 & 0.42 & 0 & 0 & 0.067 & 0.013 & 0 \\
\hline & SD & 0.54 & 8.12 & 0.74 & 10.7 & 6.95 & 4.22 & 0.39 & 0.37 & 2.09 & 0.18 & 0 & 0 & 0.02 & 0.005 & 0 \\
\hline \multirow{6}{*}{ Tomato } & Roots & 0.175 & 40.76 & 0.37 & 37.52 & 76.04 & 12.28 & 0.44 & 0.84 & 21.38 & 0.43 & 0 & 0 & 0.036 & 0.01 & 0 \\
\hline & Stem & 0.12 & 49.4 & 0.39 & 36.63 & 49.4 & 12.87 & 1.42 & 2.53 & 21.88 & 0.29 & 0 & 0 & 0.018 & 0.01 & 0 \\
\hline & Leaf & 0.13 & 44.68 & 0.39 & 34.6 & 68.64 & 12.032 & 0.82 & 1.38 & 21.92 & 0.35 & 0 & 0 & 0.022 & 0.014 & 0 \\
\hline & Fruit & 0.14 & 47.72 & 0.8 & 40.6 & 76.84 & 12.64 & 1.42 & 2.56 & 21.45 & 0.47 & 0 & 0 & 0.038 & 0.018 & 0 \\
\hline & Mean & 0.14 & 45.64 & 0.48 & 37.33 & 67.73 & 12.45 & 1.025 & 1.82 & 21.65 & 0.38 & 0 & 0 & 0.028 & 0.013 & 0 \\
\hline & SD & 0.023 & 3.79 & 0.2 & 2.49 & 12.76 & 0.37 & 0.48 & 0.85 & 0.28 & 0.08 & 0 & 0 & 0.009 & 0.003 & 0 \\
\hline \multirow{6}{*}{ Okra } & Roots & 0.12 & 47 & 0.67 & 34.16 & 79.4 & 13.78 & 0.71 & 1.05 & 24.6 & 0.55 & 0 & 0 & 0.022 & 0.01 & 0 \\
\hline & Stem & 0.19 & 43.8 & 0.44 & 39.68 & 78.56 & 20.6 & 0.6 & 1.2 & 22.26 & 0.41 & 0 & 0 & 0.036 & 0.014 & 0 \\
\hline & Leaf & 0.14 & 47.72 & 0.64 & 38.62 & 77.4 & 13.02 & 0.79 & 1.19 & 25.09 & 0.53 & 0 & 0 & 0.036 & 0.008 & 0 \\
\hline & Fruit & 0.23 & 46 & 0.49 & 45.08 & 84.08 & 19.69 & 0.51 & 1.09 & 20.85 & 0.344 & 0 & 0 & 0.034 & 0.02 & 0 \\
\hline & Mean & 0.17 & 46.13 & 0.56 & 39.38 & 79.86 & 16.77 & 0.65 & 1.13 & 23.2 & 0.45 & 0 & 0 & 0.032 & 0.013 & 0 \\
\hline & SD & 0.049 & 1.7 & 0.11 & 4.48 & 2.93 & 3.92 & 0.12 & 0.074 & 1.99 & 0.098 & 0 & 0 & 0.006 & 0.005 & 0 \\
\hline \multirow{6}{*}{$\begin{array}{l}\text { Ground } \\
\text { Nut }\end{array}$} & Roots & 0.24 & 47.44 & 0.39 & 40.56 & 92.12 & 19.63 & 0.73 & 0.94 & 25.45 & 0.38 & 0 & 0 & 0.042 & 0.014 & 0 \\
\hline & Stem & 0.24 & 45.24 & 0.42 & 30.26 & 82.56 & 18.85 & 1.02 & 1.25 & 22.08 & 0.39 & 0 & 0 & 0.044 & 0.014 & 0 \\
\hline & Leaf & 0.21 & 44.84 & 0.39 & 35.13 & 90.8 & 19.7 & 0.66 & 0.1 & 23.14 & 0.3 & 0 & 0 & 0.034 & 0.016 & 0 \\
\hline & Fruit & 0.25 & 49.48 & 0.61 & 48.49 & 91.72 & 20.97 & 1.04 & 1.43 & 23.92 & 0.35 & 0 & 0 & 0.046 & 0.018 & 0 \\
\hline & Mean & 0.23 & 46.75 & 0.45 & 38.61 & 89.3 & 19.78 & 0.86 & 0.93 & 23.64 & 0.35 & 0 & 0 & 0.041 & 0.015 & 0 \\
\hline & SD & 0.017 & 2.14 & 0.1 & 7.81 & 4.52 & 0.87 & 0.19 & 0.58 & 1.41 & 0.04 & 0 & 0 & 0.005 & 0.001 & 0 \\
\hline
\end{tabular}

Table-4: Trace Metal Content in Various Part of the World (Literature Values)

\begin{tabular}{|c|c|c|c|c|c|c|c|c|c|c|c|c|c|}
\hline Sample & Standards & $\mathrm{B}$ & $\mathrm{Ca}$ & $\mathrm{Cu}$ & $\mathrm{Fe}$ & $\mathrm{K}$ & $\mathrm{Mg}$ & $\mathrm{Mn}$ & Mo & $\mathrm{P}$ & $\mathrm{Zn}$ & $\mathrm{Pb}$ & $\mathrm{Se}$ \\
\hline \multirow{12}{*}{$\begin{array}{l}\text { Vegetable } \\
\text { plants }\end{array}$} & Gunes et.al $^{10}$ & $>20$ & & & & & & & & & & & \\
\hline & Oloyede $^{11}$ & & 248.6 & & & 223 & 235.4 & & & 12.56 & & & \\
\hline & Ethiopia $^{12}$ & & $\begin{array}{l}170- \\
320\end{array}$ & & & & & & & & & & \\
\hline & Ismail et.al ${ }^{13}$ & & $\begin{array}{l}22- \\
32\end{array}$ & & & & $\begin{array}{l}19.1- \\
32.6\end{array}$ & & & & & & \\
\hline & $\begin{array}{c}\mathrm{FAO}^{2} \mathrm{WHO}^{14} \\
2009\end{array}$ & & & 40 & 450 & & & 500 & & & 60 & & \\
\hline & Awashthi ${ }^{15}$ & & & 30 & & & & & & & 50 & & \\
\hline & Pivic RN ${ }^{16}$ & & & 20 & & & & & & & & & \\
\hline & Afzal shah et.al ${ }^{17}$ & & & & 20 & & & & & & & & \\
\hline & Kostova ${ }^{18}$ & & & & & & & & $>20$ & & & & \\
\hline & $\mathrm{WHO}^{19} 2001$ & & & & & & & & & & & 0.3 & \\
\hline & China ${ }^{20}$ & & & & & & & & & & & 0.2 & \\
\hline & Hartikainen et.al ${ }^{21}$ & & & & & & & & & & & & $>10$ \\
\hline
\end{tabular}

* Metal Concentration is $\mathrm{mg} / \mathrm{kg}$

The concentrations of trace and heavy metals in vegetable plants of selected sites were found to be in the range of $0.01-0.24 \mathrm{mg} / \mathrm{kg}$ for boron (B); $49.27-56.41 \mathrm{mg} / \mathrm{kg}$ for calcium $(\mathrm{Ca}) ; 0.028-4.65 \mathrm{mg} / \mathrm{kg}$ for copper $(\mathrm{Cu}) ; 0.72-6.29 \mathrm{mg} / \mathrm{kg}$ for iron $(\mathrm{Fe}) ; 35.05-73.47 \mathrm{mg} / \mathrm{kg}$ for potassium $(\mathrm{K}) ; 12.44-19.61 \mathrm{mg} / \mathrm{kg}$ HEAVY METALS IN VEGETABLE PLANTS 
RASĀYAN J. Chem.

Vol. 13 | No. 4 |2390-2400| October - December | 2020

for magnesium (Mg); $0.014-0.068 \mathrm{mg} / \mathrm{kg}$ for manganese $(\mathrm{Mn}) ; 0.029-0.18 \mathrm{mg} / \mathrm{kg}$ for molybdenum (Mo); $2.081-7.52 \mathrm{mg} / \mathrm{kg}$ for phosphorus $(\mathrm{P}) ; 0.022-0.28 \mathrm{mg} / \mathrm{kg}$ for zinc $(\mathrm{Zn}) ; 0.01-3.01 \mathrm{mg} / \mathrm{kg}$ for lead $(\mathrm{Pb})$; $0.008 \mathrm{mg} / \mathrm{kg}$ for selenium (Se) during pre monsoon season and $0.14-1.09 \mathrm{mg} / \mathrm{kg}$ for boron (B); 45.64$57.23 \mathrm{mg} / \mathrm{kg}$ for calcium $(\mathrm{Ca}) ; 0.45-3.54 \mathrm{mg} / \mathrm{kg}$ for copper $(\mathrm{Cu}) ; 37.33-62.44 \mathrm{mg} / \mathrm{kg}$ for iron $(\mathrm{Fe}) ; 67.73-$ $89.3 \mathrm{mg} / \mathrm{kg}$ for potassium $(\mathrm{K}) ; 12.45-23.32 \mathrm{mg} / \mathrm{kg}$ for magnesium $(\mathrm{Mg}) ; 0.65-4.87 \mathrm{mg} / \mathrm{kg}$ for manganese (Mn); $0.53-2.96 \mathrm{mg} / \mathrm{kg}$ for molybdenum (Mo); $21.65-28.3 \mathrm{mg} / \mathrm{kg}$ for phosphorus (P); $0.35-1.12 \mathrm{mg} / \mathrm{kg}$ for zinc $(\mathrm{Zn}) ; 0.028-0.61 \mathrm{mg} / \mathrm{kg}$ for lead $(\mathrm{Pb}) ; 0.013-0.097 \mathrm{mg} / \mathrm{kg}$ for selenium (Se) during post monsoon season. The graphical representation of mean trace and heavy metals content in the vegetable plant samples are shown in Fig.-2.
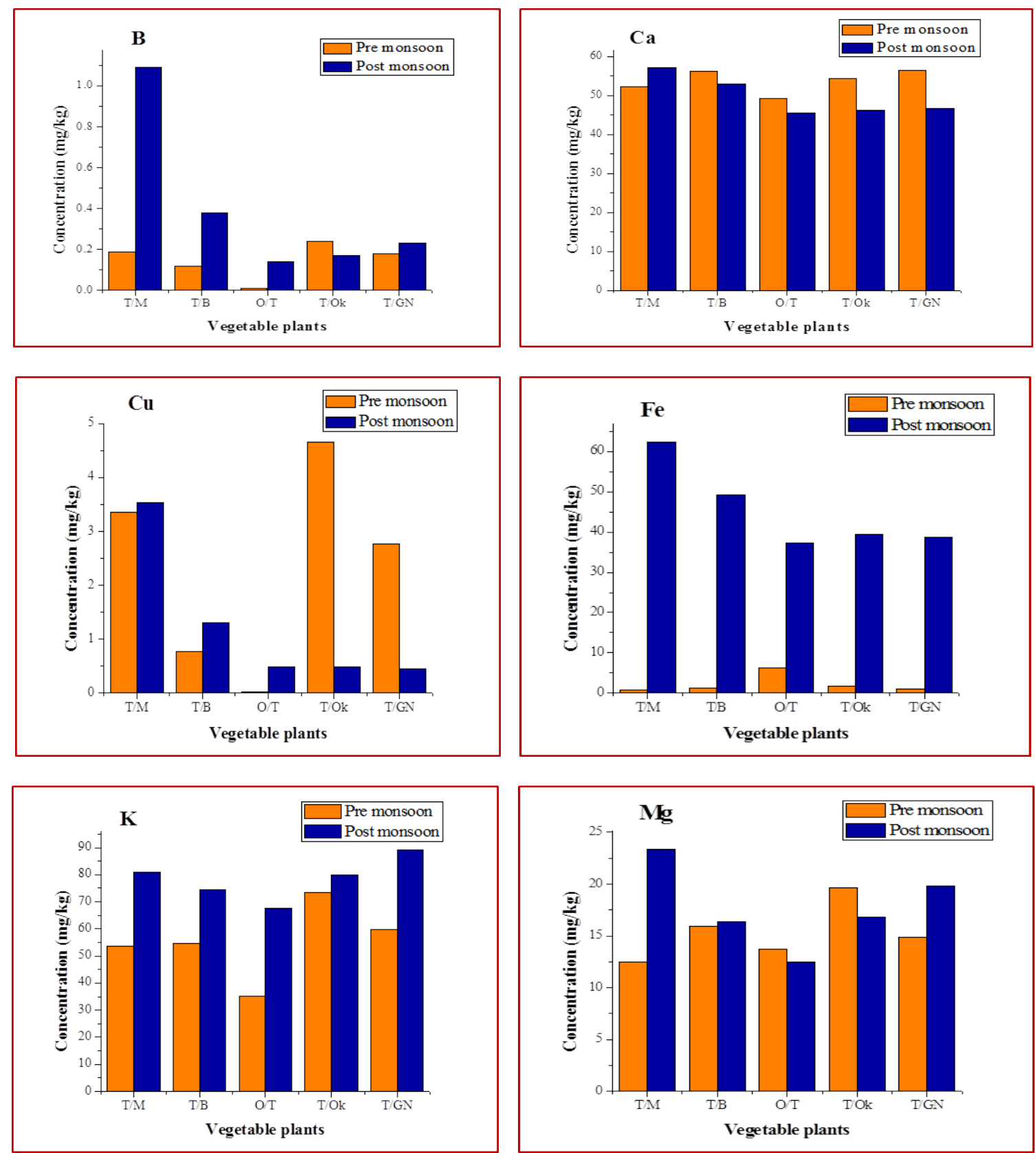
RASĀYAN J. Chem.

Vol. 13 | No. 4 |2390-2400| October - December | 2020
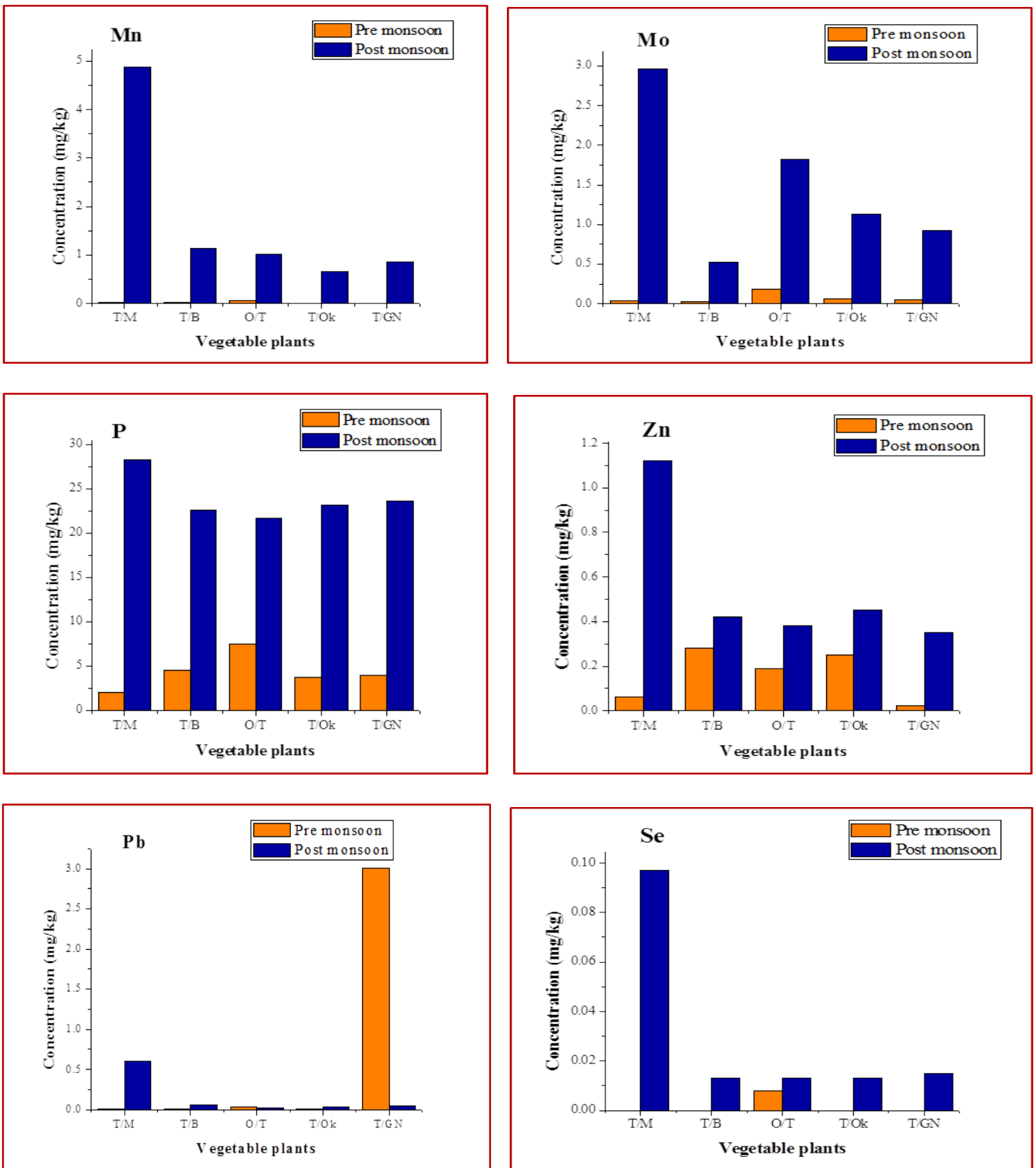

Fig.-2: Trace and Heavy Metals Mean Concentration in Vegetable Plants of Pre and Post-monsoon Season

The analytical data observed that the highest average concentration of boron $0.24 \pm 0.028 \mathrm{mg} / \mathrm{kg}$ in site IV (tomato), the lowest average concentration $0.01 \pm 0.014 \mathrm{mg} / \mathrm{kg}$ in site III (onion) during pre-monsoon and the highest average concentration $1.09 \pm 0.12 \mathrm{mg} / \mathrm{kg}$ in the site I (mirchi), lowest concentration 0.14 $\pm 0.023 \mathrm{mg} / \mathrm{kg}$ site III (tomato) during post-monsoon season. The estimated boron concentration levels are within the permissible limits during pre and post-monsoon season when compared with the reported value. ${ }^{10}$ However, boron levels are a little higher than the reported values during the post-monsoon season in all investigated sites of vegetable plants except site IV (tomato) may be due to the influence of season. The calcium concentration levels are decreased in the post-monsoon season when compared to premonsoon season in all studied sites, except site I (mirchi). The highest and lowest concentrations of calcium are $56.41 \pm 22.29 \mathrm{mg} / \mathrm{kg}$ in site V (tomato), $49.27 \pm 35.82 \mathrm{mg} / \mathrm{kg}$ in site III (onion) during premonsoon, $57.23 \pm 10.68 \mathrm{mg} / \mathrm{kg}$ in the site I (mirchi), $45.64 \pm 3.79 \mathrm{mg} / \mathrm{kg}$ in site III (tomato). The obtained 
RASĀYAN J. Chem.

Vol. 13 | No. 4 |2390-2400| October - December | 2020

calcium levels in vegetable plants are within the limits compared to reported values ${ }^{11-13}$ (Table-4), and sufficient in all studied vegetable plants during pre and post-monsoon seasons.

The obtained copper concentration levels are increased in studied vegetable plants at the site I, II and III but decreased in site IV and V during the post-monsoon season compared to pre-monsoon season. The maximum and minimum concentration of copper found to be $4.65 \pm 1.51 \mathrm{mg} / \mathrm{kg}$ in site IV (tomato) 0.028 $\pm 0.04 \mathrm{mg} / \mathrm{kg}$ in site III (onion) during pre-monsoon and $3.54 \pm 0.54 \mathrm{mg} / \mathrm{kg}$ in site I (mirchi) $0.45 \pm 0.1$ $\mathrm{mg} / \mathrm{kg}$ in site V (groundnut) during post-monsoon season. These values are slightly higher than other food samples such as chana daal, moth bean, mung bean, pearl millet, masoor ki daal and it has been reported very recently. ${ }^{14}$ The calculated experimental values are found to be within the limits as compared to literature values ${ }^{15-17,22,23}$ in all investigated vegetable plants at both seasons.

It is observed that iron concentration was gradually increased during the post-monsoon season compared to pre-monsoon season in all studied vegetable plants. The highest concentration of iron $6.29 \pm 8.69$ $\mathrm{mg} / \mathrm{kg}$ in site III (onion), $62.44 \pm 4.8 \mathrm{mg} / \mathrm{kg}$ in the site I (mirchi) and the lowest concentration $0.72 \pm 0.39$ $\mathrm{mg} / \mathrm{kg}$ in site I (tomato), $37.33 \pm 2.49 \mathrm{mg} / \mathrm{kg}$ in site III (tomato) during pre and post-monsoon seasons are found. However, iron concentration levels are found to be low during the pre-monsoon season, but acceptable range in post-monsoon season in all vegetable plants when compared to literature reported values. ${ }^{15,18}$

Potassium concentration levels were progressively increased in all investigated vegetable plants during the post-monsoon season compared to the pre-monsoon season. From the experimental data, the maximum concentration of $\mathrm{K} 73.47 \pm 51.29 \mathrm{mg} / \mathrm{kg}$ in site IV (tomato), $89.3 \pm 4.52 \mathrm{mg} / \mathrm{kg}$ in site V (groundnut) and minimum concentration $35.05 \pm 7.48 \mathrm{mg} / \mathrm{kg}$ in site III (onion), $67.73 \pm 12.76 \mathrm{mg} / \mathrm{kg}$ in site III (tomato) during pre and post-monsoon seasons were noticed. The obtained analytical values were compared and found to be within the limits of literature reported values ${ }^{11}$ in all the studied vegetable plants in both seasons.

The obtained magnesium concentration levels in all vegetable plants $(12.4-23.32 \mathrm{mg} / \mathrm{kg})$ in both seasons are found to be good comparable with reported by Ismail et.al ${ }^{13}$, but magnesium was found to lower concentration when compared with Oloyede. ${ }^{11}$ During the seasonal variation, it is found that magnesium levels increased in the site I, II and V, but decreased in site III and IV in the post-monsoon season compared with pre-monsoon season. The maximum and minimum concentration of $\mathrm{Mg} 19.61 \pm 8.04$ $\mathrm{mg} / \mathrm{kg}$ in site IV (tomato), $12.44 \pm 8.88 \mathrm{mg} / \mathrm{kg}$ in site I (tomato) during pre-monsoon and $23.32 \pm 1.97$ $\mathrm{mg} / \mathrm{kg}$ in site I (mirchi), $12.45 \pm 0.37 \mathrm{mg} / \mathrm{kg}$ in site III (tomato) during the post-monsoon season were observed.

According to $\mathrm{FAO} / \mathrm{WHO}$ (2007), the manganese levels are lower in all investigated vegetable plants in both seasons compared with safe limit. ${ }^{14}$ However, Manganese concentration levels are increased in all the sites under investigation during post-monsoon compared with pre-monsoon season. The highest $\mathrm{Mn}$ concentration is found to be $0.068 \pm 0.096 \mathrm{mg} / \mathrm{kg}$ in site III (onion), $4.87 \pm 1.99 \mathrm{mg} / \mathrm{kg}$ in site I (mirchi) and lowest concentration is $0.014 \pm 0.029 \mathrm{mg} / \mathrm{kg}$ in site I (tomato), $0.65 \pm 0.12 \mathrm{mg} / \mathrm{kg}$ in site IV (okra) during pre and post-monsoon season.

The maximum concentration of molybdenum is $0.18 \pm 0.22 \mathrm{mg} / \mathrm{kg}$ in site III (onion), $2.96 \pm 0.72 \mathrm{mg} / \mathrm{kg}$ in site I (mirchi) and minimum concentration is $0.029 \pm 0.006 \mathrm{mg} / \mathrm{kg}$ in site II (tomato), $0.53 \pm 0.37$ $\mathrm{mg} / \mathrm{kg}$ in site II (brinjal) during pre and post-monsoon season is found. The obtained concentration levels are increased in all vegetable plants during the post-monsoon season compared with the pre-monsoon season. Molybdenum concentration levels are within the acceptable range in all vegetable plants in both seasons with literature reported value. ${ }^{24}$

It is observed that phosphorus concentration levels are gradually increased in all investigated vegetable plants during post-monsoon season compare to pre-monsoon season. The highest average concentration of P $7.52 \pm 0.45 \mathrm{mg} / \mathrm{kg}$ in site III (onion), $28.3 \pm 2.7 \mathrm{mg} / \mathrm{kg}$ in the site I (mirchi) and lowest concentration $2.081 \pm 1.092 \mathrm{mg} / \mathrm{kg}$ in the site I (tomato), $21.65 \pm 0.28 \mathrm{mg} / \mathrm{kg}$ in site III (tomato) during pre and postmonsoon season are found. The pre-monsoon experimental values are good comparable with literature value and post-monsoon experimental values are exceeded the literature value. ${ }^{11}$ However, this higher concentration may not affect the vegetable plants, animals and humans due to its nutritional and biological importance. 
RASĀYAN J. Chem.

Vol. 13 | No. 4 |2390-2400| October - December | 2020

The concentration levels of zinc were increased in all vegetable plants during the post-monsoon season compared with pre-monsoon season. The maximum concentration of zinc $0.28 \pm 0.2 \mathrm{mg} / \mathrm{kg}$ in site II (tomato), $1.12 \pm 0.27 \mathrm{mg} / \mathrm{kg}$ in site I (mirchi) and minimum concentration is $0.022 \pm 0.019 \mathrm{mg} / \mathrm{kg}$ in site $\mathrm{V}$ (tomato), $0.35 \pm 0.04 \mathrm{mg} / \mathrm{kg}$ in site $\mathrm{V}$ (groundnut) during pre and post-monsoon season were observed. Zinc concentrations are found to be lower levels in all vegetable plants compared with reported values ${ }^{15,16}$ in both seasons.

It is found that lead concentration levels increased in all plant samples during post-monsoon season compare to pre-monsoon season, except site V. The estimated quantitative values are found to be within the permissible levels in all vegetable plants at both seasons compared with literature reported values. ${ }^{19,20}$ However, lead concentration was found to be higher at site V $3.01 \pm 5.99 \mathrm{mg} / \mathrm{kg}$ (tomato) in pre-monsoon and site I (mirchi) $0.61 \pm 0.43 \mathrm{mg} / \mathrm{kg}$ in post-monsoon season. Therefore, higher lead concentration is a major path to reach the plants and subsequently influence human health if any such consumption of vegetables.

Obtained selenium concentration levels are found to be increased during the post-monsoon season when compared to the pre-monsoon season. The experimental values of selenium in both seasons are moderately low in all investigated vegetable plants compared to the literature reported value. ${ }^{22}$ It is observed that selenium was found to be in the range from $0.008-0.097 \mathrm{mg} / \mathrm{kg}$ in both seasons.

\section{Statistical Data}

In correlation analysis, the bivariate method is being adopted to describe the relation between two different metals. The high correlation coefficient $(\mathrm{r}=$ higher than 0.7$)$ indicates a strong correlation between two metals. ${ }^{25}$ Pearson Correlation coefficient data for trace metals in the edible part (vegetable) for pre and post-monsoon season are shown in Table-5.

Table-5: Pearson Correlation Coefficients (r) Data of Trace and Heavy Metals in Edible Parts for Pre and Postmonsoon Season

\begin{tabular}{l|r|r|r|r|r|r|r|r|r|r|r}
\hline & \multicolumn{1}{c|}{$\mathrm{B}$} & $\mathrm{Ca}$ & $\mathrm{Cu}$ & $\mathrm{Fe}$ & $\mathrm{K}$ & $\mathrm{Mg}$ & $\mathrm{Mo}$ & $\mathrm{P}$ & $\mathrm{Zn}$ & $\mathrm{Pb}$ & $\mathrm{Se}$ \\
\hline $\mathrm{B}$ & 1 & & & & & & & & & & \\
\hline $\mathrm{Ca}$ & $* 0.91$ & 1 & & & & & & & & & \\
\hline $\mathrm{Cu}$ & $* 0.9$ & 0.65 & 1 & & & & & & & & \\
\hline $\mathrm{Fe}$ & $* 0.89$ & $* 0.83$ & $* 0.79$ & 1 & & & & & & & \\
\hline $\mathrm{K}$ & $* 0.87$ & $* 0.7$ & $* 0.89$ & $* 0.95$ & 1 & & & & & & \\
\hline $\mathrm{Mg}$ & $* 0.89$ & $* 0.79$ & $* 0.84$ & $* 0.94$ & $* 0.95$ & 1 & & & & & \\
\hline $\mathrm{Mo}$ & $* 0.79$ & 0.48 & $* 0.95$ & 0.61 & $* 0.77$ & $* 0.73$ & & & & & \\
\hline $\mathrm{P}$ & -0.74 & -0.79 & -0.52 & -0.41 & -0.33 & -0.47 & -0.5 & 1 & & & \\
\hline $\mathrm{Zn}$ & -0.003 & -0.16 & 0.179 & 0.26 & 0.41 & 0.42 & 0.22 & 0.47 & & & \\
\hline $\mathrm{Pb}$ & -0.45 & -0.7 & -0.09 & -0.37 & -0.12 & -0.16 & 0.1 & 0.6 & $* 0.7$ & & 1 \\
\hline $\mathrm{Se}$ & -0.92 & -0.99 & -0.67 & -0.82 & -0.7 & -0.78 & -0.52 & $* 0.82$ & 0.2 & $* 0.7$ & 1 \\
\hline
\end{tabular}

\begin{tabular}{|c|c|c|c|c|c|c|c|c|c|c|c|c|}
\hline \multicolumn{13}{|c|}{ Post monsoon Season } \\
\hline & B & $\mathrm{Ca}$ & $\mathrm{Cu}$ & $\mathrm{Fe}$ & $\mathrm{K}$ & $\mathrm{Mg}$ & $\mathrm{Mn}$ & Mo & $\mathrm{P}$ & $\mathrm{Zn}$ & $\mathrm{Pb}$ & $\mathrm{Se}$ \\
\hline B & 1 & & & & & & & & & & & \\
\hline $\mathrm{Ca}$ & $* 0.81$ & 1 & & & & & & & & & & \\
\hline $\mathrm{Cu}$ & 0.67 & $* 0.94$ & 1 & & & & & & & & & \\
\hline $\mathrm{Fe}$ & 0.64 & $* 0.92$ & *0.94 & 1 & & & & & & & & \\
\hline $\begin{array}{l}\text { Continued } \\
\text { Table } .5 \\
\mathrm{~K}\end{array}$ & -0.08 & 0.28 & 0.24 & 0.52 & 1 & & & & & & & \\
\hline
\end{tabular}


RASĀYAN J. Chem.

Vol. 13 | No. 4 |2390-2400| October - December | 2020

\begin{tabular}{l|r|r|r|r|r|r|r|r|r|r|r|r}
\hline $\mathrm{Mg}$ & 0.6 & $* 0.71$ & 0.64 & $* 0.85$ & 0.7 & 1 & & & & & & \\
\hline $\mathrm{Mn}$ & 0.68 & $* 0.88$ & $* 0.85$ & 0.69 & -0.05 & 0.31 & 1 & & & & & \\
\hline $\mathrm{Mo}$ & -0.45 & 0.06 & 0.28 & 0.13 & 0.08 & -0.29 & 0.29 & 1 & & & & \\
\hline $\mathrm{P}$ & 0.43 & $* 0.83$ & $* 0.75$ & $* 0.85$ & $* 0.7$ & $* 0.73$ & 0.66 & 0.24 & 1 & & & \\
\hline $\mathrm{Zn}$ & $* 0.78$ & $* 0.93$ & $* 0.95$ & $* 0.83$ & -0.01 & 0.5 & $* 0.92$ & 0.18 & 0.62 & 1 & & \\
\hline $\mathrm{Pb}$ & 0.54 & $* 0.88$ & $* 0.97$ & $* 0.96$ & 0.39 & 0.68 & $* 0.75$ & 0.35 & $* 0.78$ & $* 0.87$ & 1 & \\
\hline $\mathrm{Se}$ & -0.4 & -0.84 & -0.94 & -0.91 & -0.43 & -0.58 & -0.77 & -0.52 & -0.83 & -0.82 & -0.97 & 1 \\
\hline
\end{tabular}

*indicating that good correlation between two metals

In pre monsoon season, $\mathrm{B}$ is showing good correlation with $\mathrm{Ca}(0.91), \mathrm{Cu}(0.9), \mathrm{Fe}(0.89), \mathrm{K}(0.87), \mathrm{Mg}$ (0.89) and Mo (0.79); Ca is showing good correlation with $\mathrm{Fe}(0.83), \mathrm{K}(0.7)$ and $\mathrm{Mg}(0.79)$; $\mathrm{Cu}$ is showing strong correlation with $\mathrm{Fe}(0.79), \mathrm{K}(0.89), \mathrm{Mg}(0.84)$ and $\mathrm{Mo}(0.95) ; \mathrm{Fe}$ is showing strong correlation with $\mathrm{K}(0.95), \mathrm{Mg}(0.94)$; $\mathrm{K}$ is showing good correlation with $\mathrm{Mg}(0.95)$ and $\mathrm{Mo}(0.77)$; Mo (0.73) correlate with $\mathrm{Mg}$; Se (0.82) correlate with $\mathrm{P}$; $\mathrm{Pb}(0.7)$ correlate with $\mathrm{Zn}$, and $\mathrm{Se}(0.7)$ correlate with $\mathrm{Pb}$. In post monsoon season $\mathrm{B}$ is showing strong correlation with $\mathrm{Ca}(0.81)$ and $\mathrm{Zn}(0.78)$; $\mathrm{Ca}$ is shows good correlation with $\mathrm{Cu}(0.94), \mathrm{Fe}(0.92), \mathrm{Mg}(0.71), \mathrm{Mn}(0.88), \mathrm{P}(0.83), \mathrm{Zn}(0.93)$ and $\mathrm{Pb}$ (0.88); $\mathrm{Cu}$ is found to be good correlation with $\mathrm{Fe}(0.94), \mathrm{Mn}(0.85), \mathrm{P}(0.75), \mathrm{Zn}(0.95)$ and $\mathrm{Pb}(0.97)$; $\mathrm{Mg}(0.85), \mathrm{P}(0.85), \mathrm{Zn}(0.83)$, and $\mathrm{Pb}(0.96)$ found to be strongly correlate with $\mathrm{Fe} ; \mathrm{P}(0.7,0.73)$ correlate with $\mathrm{K}$ and $\mathrm{Mg} ; \mathrm{Zn}(0.92)$ and $\mathrm{Pb}(0.75)$ strongly correlate with $\mathrm{Mn} ; \mathrm{Pb}(0.78,0.87)$ correlate with $\mathrm{P}$ and $\mathrm{Zn}$. This indicate that, the correlation of these metals occurring through various sources like crustal contamination, use of pesticides, fertilizers, atmospheric particulate deposition, anthropogenic activities, industrialization, mining activities etc.

\section{CONCLUSION}

The present investigation has explored quantitative analytical data on trace and heavy metals in vegetable plants, which were cultivated surrounding agricultural fields of the uranium mining site, tummalapalli, A.P. The comparison of seasonal data few metals are increased in post-monsoon season such as, $\mathrm{Fe}, \mathrm{K}$, $\mathrm{Mn}, \mathrm{Mo}, \mathrm{P}, \mathrm{Zn}$ and Se in all fields of vegetable plants. It may be due to seasonal variation, plumbing, atmospheric pollutants, the addition of fertilizers, organic manures, and rainfall. The observed levels are comparable with the literature reported values from various regions of the world. Further, it has been observed that all metals are increased in C. annum (green chilli) during the post-monsoon season at site I. The studied metals were within the permissible limits in all vegetable plants at both seasons, except lead $(\mathrm{Pb})$ in site $\mathrm{V} 3.01 \mathrm{mg} / \mathrm{kg}$ (tomato) during pre-monsoon and site I (mirchi) $0.61 \mathrm{mg} / \mathrm{kg}$ during postmonsoon season found to be higher. The concentration of trace and heavy metals in the studied vegetable plants were acceptable for human consumption except for $\mathrm{Pb}$ at site $\mathrm{V}$ and site I during pre and postmonsoon respectively.

\section{ACKNOWLEDGMENT}

The authors convey their gratitude to university officials and JNTUACEP Principal for providing the lab facilities for this study.

\section{REFERENCES}

1. Saied Nazemi, Journal of Applied Environmental and Biological Sciences, 2, 386(2012).

2. J. Khairiah, M.K. Zalifah, Y.H. Yin and A. Aminha, Pakistan Journal of Biological Sciences, 7, 1438(2004), DOI: 10.3923/pjbs.2004.1438.1442.

3. K. Chojnacka, A.Chojnacki ,H Gorecka and H. Gorecki , The Science Total Enviroment, 337,175(2005), DOI:10.1016/j.scitotenv.2004.06.009.

4. Y. Yang, F.S. Zhang, H.F. Li and R.F. Jiang, Journal Environment Management, 90, 1117(2009), DOI: 10.1016/j.jenvman.2008.05.004.

5. J. Hu, F. Wu, S. Wu, Z. Cao, X. Lin and M.H. Wong, Chemosphere, 91, 455(2013), Journal of Environmetal Biology, 32, 831(2011), DOI:10.1016/j.chemosphere.2012.11.066.

6. J. Nouri, N. Khorasani, B. Lorestani, M. Karami, A.H Hassani and N. Yousefi, Environmental Earth Science, 59, 315(2009), DOI:10.1007/s12665-009-0028-2. 
RASĀYAN J. Chem.

Vol. 13 | No. 4 |2390-2400| October-December | 2020

7. S. Khan, Q. Cao, Y.M. Zheng, Y.Z. Huang and Y.G.Zhu, China Environmenta Pollution, 152, 686(2008), DOI:10.1016/j.envpol.2007.06.056.

8. S. Khan, Q. Cao, Y. M. Zheng, Y. Z. Huang, Y. G. Zhu, Environmental Pollution, 152, 686(2008)

9. Noor-ul Amin and Tauseef Ahmad, Royal Society of Chemistry, 5, 14322(2015).

10. A. Gunes, G. Soylemezoglu, A. Inal, E.G. Bagci, S.Coban and O. Sahin, Scientia Horticulture,110, 279(2006), DOI:10.1016/j.scienta.2006.07.014.

11. O.P. Oloyede, Pakistan Journal of Nutrition, 4, 379(2005)

12. Ethiopia Health and Nutritional Research Institute (1998), Food Composition Table for Use in Ethiopia, EHNRI and FAO of the UN, Addis Ababa, Ethiopia.

13. F. Ismail, M.R. Anjum, A.N. Mamon and T.G Kazi, Journal of Nutrition, 10, 365(2011), DOI: $10.3923 /$ pjn.2011.365.372.

14. FAO/WHO (2007), Joint FAO/WHO Food Standard Programme Codex Aliment Arius Commission (Report of the Thirty Eight Session of the Codex Committee on Food Hygiene), Houston, USA. $\mathrm{ftp} / / / \mathrm{ftp}$.fao.org/codex/Reports/Alinorm07/al30/13.

15. S.K. Awashthi (2000), Prevention of Food Adulteration Act no. 37 of 1954, Central and State Rules as Amended for 1999, Ashoka Law House, New Delhi.

16. R. N. Pivic, A. B. S. Sebic and D.L. Josic, Polish Journal Environmental Studies, 22, 1456(2013)

17. Afzal Shah, Abdul Niaz, Nazeef Ullah, Ali Rehman, Muhammad Akhlaq and Muhammad Zakir, Journal of Chemistry, Article ID 621265,1(2013), DOI:10.1155/2013/621265.

18. D. Kostova, V. Kanazirska and M. Kamburova, Agronomy Research, 6, 477(2008)

19. Codex Alimentarius Commission (FAO/WHO), Food Additives and Contaminants, Joint FAO/WHO Food Standards Program, 2001, ALINORM 01/12A: 1-289.

20. Chinese Department of Preventive Medicine (1994), Threshold For Food Hygiene, Beijing: China Standard Press.

21. H. Hartikainen, T. L. Xue and V. Piironen, Plant and Soil, 225, 93(2000), DOI: 10.1023/A:1026512921026.

22. Pallavi Mishra, Rajshri Soni, Vandana Kachhwaha and Naresh Giri, Rasayan Journal of Chemistry, 13(1), 210(2020), DOI:10.31788/RJC.2020.1315570.

23. N. Shobha and B. M. Kalshetty, Rasayan Journal of Chemistry, 10(1), 124(2017), DOI: 10.7324/RJC.2017.1011575.

24. D. Kostova, V. Kanazirska and M. Kamburova, Agronomy Research, 6, 477(2008)

25. M.S.R. Sharma and N. S. Raju, International Research Journal of Environmental Science, 2, 22(2013)

[RJC-5869/2020] 